\title{
Educational Technology and Principles and Methods of Teaching English
}

\author{
Ali Ashrafi ${ }^{1 *}$ iD \\ ${ }^{1}$ English Department, Azad Islamic University, Shahr-e-Qods Branch, Tehran, Iran
}

*Corresponding author: ali.ashrafi.sarvak11@gmail.com

\begin{abstract}
Abstrak
Penggunaan berbagai teknologi audio visual dalam proses belajar mengajar sangatlah penting. Namun, salah satu keterampilan dan pengetahuan guru yang paling penting adalah keakraban dengan teknologi ini dalam bahasa Inggris. Tujuan dari penelitian ini adalah untuk menganalisis inovasi instruktif berupa pemanfaatan aset PC dalam pembelajaran bahasa Inggris. Penyelidikan saat ini dipimpin menggunakan strategi pencerahan yang dikumpulkan oleh prosedur perpustakaan, yang dikumpulkan dengan mempertimbangkan inovasi pendidikan, masalah terkait, artikel, dan buku yang telah dirujuk dalam referensi. Hasil penelitian ini menunjukkan bahwa pemandu yang mendorong sebagai antarmuka memiliki opsi untuk melakukan tugasnya dengan baik. Akan lebih baik jika instruktur memiliki keterampilan dasar untuk menggunakan perangkat ini. Karena masalah sistem pembelajaran bangsa kita dalam menampilkan bahasa Inggris dan kurangnya keterampilan siswa yang terlatih, terutama dalam berbicara, mendengarkan, dan menulis, banyak wali mencoba untuk menutupi kekurangan dalam sistem pembelajaran ini dengan beralih ke state-of -sekolah seni. Oleh karena itu, dalam artikel ini, kami memilih untuk menganalisis tugas mendorong kemajuan bantuan dalam mempromosikan pengajaran bahasa Inggris di wali kelas. Jadi, dapat disimpulkan bahwa penggunaan sumber daya PC, serta e-learning, dapat membantu guru di kelas dan mengingat itu meningkatkan ide pelatihan dan membuat siswa bersemangat untuk belajar.
\end{abstract}

Kata kunci: Teknologi Pendidikan, Bahasa Inggris.

\section{Abstract}

The use of various audio-visual technologies in the teaching and learning process is very important. However, one of the most important teacher skills and knowledge is familiarity with this technology in English. The purpose of this study was to analyze the instructive innovation in the form of utilizing PC assets in learning English. The current investigation was led using enlightenment strategies accumulated by library procedures, which were collected taking into account educational innovations, related issues, articles, and books which have been referenced in the references. The results of this study show that encouraging guides as interfaces have options to do their job well. It would be better if the instructor had basic skills to use this device. Due to the problems of our nation's learning system in displaying English and the lack of trained students' skills, especially in speaking, listening, and writing, many guardians are trying to make up for this deficiency in the learning system by turning to state-of-the-art schools. Therefore, in this article, we have chosen to analyze the task of encouraging progress of assistance in promoting the teaching of English in the homeroom. So, it can be concluded that the use of PC resources, as well as e-learning, can help teachers in the classroom and remember that it enhances training ideas and makes students excited to learn.

Keywords: Educational Technology, English

\begin{tabular}{ll}
\hline History: & Publisher: Undiksha Press \\
Received : February 19, 2021 & Licensed: This work is licensed under \\
Revised : March 18, 2021 & a Creative Commons Attribution 3.0 License \\
Accepted : April 10, 2021 &
\end{tabular}

\section{Introduction}

Learning occurs when standard components meet. Instructive space, instructive substance, rules and guidelines, and educators and exhibit physical aid and state of mind. The influence of innovation on training has been concentrated by many scientists over the last forty years. The most obvious and common exploratory findings in this area are identified with the effects of innovation in learning, the utilization and non-use (ICT) components of training, and how to encourage their use in educational models (Arrosagaray et al., 2019; Ogawa et al., 2020; Valtonen et al., 2015). In line with the development of data innovation and the entry of broadcast communication into the depths of society, teaching tools and 
techniques are also increasingly advanced. These instruments and techniques advance with the aim that everyone and any place can study in their office and at their designated time.

Today, with the introduction of new instructive innovations and particularly Internet access among comprehensive networks in schools and their impact on communities worldwide and non-indigenous, a situation has emerged. Training is inevitably adapted to new needs following the wishes of the times. Selecting and achieving new capacities requires another audit of the instruction framework. English with four talents (tuning in, speaking, reading, and writing). Instructive innovation and new arrangements are needed. PCs and instructive programs are some of the most appropriate English language show tools of the last decade. Therefore, the fundamental focal point of instructive innovation in language education has been centered on this segment, and the planning and assessment of educational and educational programs rely on this standard. Appropriate use of PCs, TV, cassettes, media, customized learning materials, and a variety of strategies give instructors better opportunities to plan individual work and meetings with students (Arrosagaray et al., 2019; Chen \& Thomas, 2020; Scagnoli et al., 2019).

Using innovative tools appropriately will keep teachers from appearing as speakers and create the kind of mental climate in the classroom that encourages true learning. These tools help educators become experts, and using training helps students and instructors not rely on course readings as single course readings. Instructive innovations are meant to help provide this kind of preparation. PCs and innovation are a critical danger and source of uncertainty for instructors around the world; Websites and web journals, wikis, programming, magazines, and more. They can mask the stability of the employer instructor. Several countries have put forth significant institutional efforts to make their devices more brilliant, and therefore, beneficial results of PCs in language teaching have been demonstrated. However, there is interest and good fortune among many language educators to use PCs in language teaching. Also, the lack of adequate opportunities to commit to extracurricular exercises and the challenges of consolidating new examples in the study space are among the main reasons.

The instructor's mentality and considerations greatly affect the use of critical registers in the study room. It also underlines that educators' own beliefs about the use of innovations in language show a dynamic impact, which is a fundamental factor influencing their adoption of innovations. Moreover, the interesting relationship between innovation and learning space depends on the instructors themselves, for example, their derivation and disposition. It should also be pointed out that educators' assumptions and perspectives on teaching and innovation can be viewed as loosening and encouraging elements that provide them with sufficient certainty to take advantage of innovation. The educator's personal record, such as individual certainty, interest in using innovation, and desire for new techniques, are all important factors that can significantly influence innovation and PC in the classroom. Institutional associations, study sheets (territorial and public), and even distributors direct their concentration to remote and online training. Furthermore, the PC is not, at this point, the sole instrument for sending messages and seeking information.

The use of various audio-visual technologies in the teaching and learning process is very important. However, one of the most important teacher skills and knowledge is familiarity with this technology in English. Computers and educational software are one of the most practical English teaching tools in the last decade. Therefore, the main focus of educational technology in language teaching has been focused on this section, and the evaluation of curriculum and teaching is based on this principle. Instructive innovation is perhaps the most fundamental thing in learning and educating, and by making use of the latest innovations on the planet, the level of learning can be increased and the awareness of the general public can be increased further (Gogate et al., 2020; Hao et al., 2020; Seçer et al., 
2015). The consequences of logical exploration have shown that different faculties do not take equal parts in learning. This is the main reason for using educational innovations because it can include multiple detections and duplication of feasibility.

Instructive innovation provides instructors with tools and techniques to help them overcome instructive problems. Preparing for the use of educational innovations also plays an important role in scientific achievement and expands the level of student learning. It is quite possible that the primary task of education providers is to help use more and better innovation advances to improve the nature of training. Students use helpful teaching to offer objectivity to learning and demonstrate a measure of and effectively engage with educating and learning new exercises. Many authors have described instructive innovation (Glaveanu et al., 2020; Huang et al., 2021). More often than not, though, they have analyzed various instructive innovation strategies. Instructive innovations, especially new advances, affect students' implementation of language learning differently. The investigation of the impact of instructive innovation on language students has been the subject of examination by school experts for a long time. In this exam, the relationship between learning and instructive innovation in various measures has been considered.

The results obtained from most of these investigations have shown constructive results from these advances in the language learning cycle of students. Study time is reduced when using PC in preparation compared to ordinary techniques, in the end, learning speed is increased. They influence student learning more. The use of recreational and scientific programs can significantly improve students' numerical performance. The use of PCs in training accelerates student learning and increases their confidence and confidence in learning. Learning innovations help students achieve learning goals and improve basic skills, such as reading, writing, and number juggling. Instructive innovation attracts students with learning, and hence, they invest more energy in completing their work. Several studies relevant to this research were conducted by (Anderson \& Davidson, 2019) who found that receptive and interactive screen media increased different types of understanding and learning. Then the research conducted by (Scagnoli et al., 2019) found video lectures to be effective in college teaching and learning and their implications for practical implications in online course design. Another study also found that the hand-drawn type of video lecture was rated as the most engaging and supported memory performance of individuals with low prior knowledge of the content material (Chen \& Thomas, 2020). The purpose of this study is to analyze instructive innovations in the form of utilizing PC assets in learning English.

\section{Methods}

The current investigation was led utilizing an enlightening strategy that accumulated by library procedure, which was gathered by considering educational innovation, related issues, articles and books which have referenced in the reference.

\section{Results and Discussion}

The concept of teaching aids. Anything that can build the nature of educating and learning is an instructing helps. The media where the first media is utilized in schooling, which has followed by other media, for example, pictures, maps, slides, films, and numerous other media that entered the instruction cycle. The importance of teaching aids.Exploration shows that through common instructing (customary schooling), just $30 \%$ of the material is found out, while if the learning is finished with the right utilization of specialized devices, it will expand the pace of $75 \%$. Benefits of educational tools and technologies. Educational technology has the potential to improve the teaching / learning process. Improve the teaching / learning process benefits via educational technology can be seen in Figure 1. 


\section{Features of educational tools}

Training helps incorporate media, pictures, the utilization of plays, instructive games, and the production of little gatherings of understudies for learning exercises and tastes that make learning entirely alluring and appealing, and the reason for utilizing an assortment of encouraging guides is to encourage and facilitate educating and learning. The utilization of instructive materials and apparatuses causes more consideration of students and accordingly lessens the effect of actual hindrances of correspondence and sets up more correspondence and comprehension among educator and understudy. Truth be told, training helps are a piece of instructive innovation that means to tackle instructive issues constantly, by inspecting and controlling all the elements influencing learning and set of parts of the instructive cycle. Accomplishing this objective is certifiably not a simple assignment in light of the fact that notwithstanding the fundamental changes and changes in the conventional educator focused framework, the logical and viable fitness of instructors should be improved through the important preparing, which is one of the approaches to perceive and apply various ideas. Teaching features of Ordinary teaching \& Teaching aids can be seen on Table 1.

Table 1. Teaching features of Ordinary teaching \& Teaching aids

\begin{tabular}{cllc}
\hline & Teaching tools & \multicolumn{1}{c}{ Teaching features } & $\begin{array}{c}\text { Percentage of content } \\
\text { learning }\end{array}$ \\
\hline $\begin{array}{c}\text { Ordinary } \\
\text { teaching }\end{array}$ & $\begin{array}{l}\text { Traditional learning } \\
\text { tools such as books } \\
\text { and pamphlets }\end{array}$ & $\begin{array}{l}\text { Group learning } \\
\text { The quality of ordinary } \\
\text { education } \\
\text { Unequal educational } \\
\text { opportunities }\end{array}$ & $30 \%$ \\
$\begin{array}{c}\text { Teaching } \\
\text { aids }\end{array}$ & $\begin{array}{l}\text { Images, maps, slides, } \\
\text { videos and many other } \\
\text { media }\end{array}$ & $\begin{array}{l}\text { Individual training } \\
\text { Improving the quality of } \\
\text { teaching } \\
\text { Creating } \\
\text { educational opportunities }\end{array}$ & $75 \%$ \\
\hline
\end{tabular}

\section{Discussion}

The appearance of new advancements has expanded the interest in getting information differently and appropriate for various circumstances. It very well may be asserted that the measure of human data pairs at regular intervals all in all, the all-out data accessible to an understudy in 1997 is short of what one percent of the data that will be accessible to different understudies in 2050. In this manner, because of the immense and inescapable changes in social orders, individuals need present day schooling to react to the mind-boggling requirements of current culture, which won't be conceivable but to change the instruction framework and change learning conditions (Lazonder et al., 2020; Mayer et al., 2020) . The necessity of using technology in the educational system can be seen in Figure 2. 


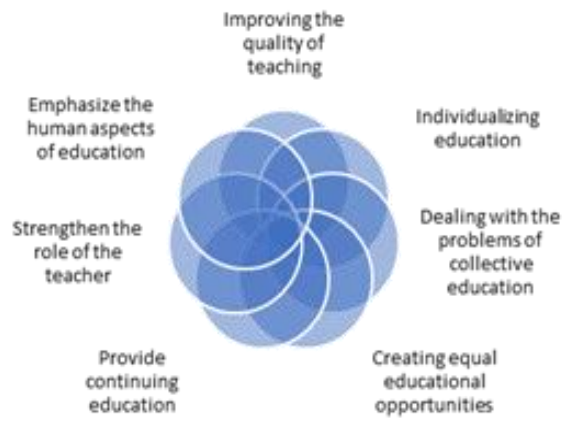

Figure 1. Improve the teaching / learning process benefits via educational technology

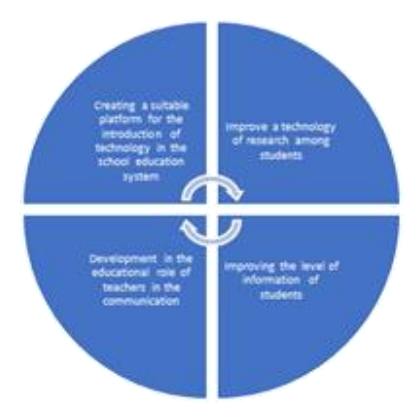

Figure 2. The necessity of using technology in the educational system

Perhaps the main things for effective language learning are the accessibility and allure of the substance. In any case, for some language students, both in the study hall and the individuals who learn at home, such access is typically restricted by ICT arrangements (Lazonder et al., 2020). That is the reason language instructors have since quite a while ago considered data and correspondence innovations for this issue. Improving practical admittance to computerized and mixed media advances used to get to instructive materials. These advancements are regularly savvier than printed media or recorded sound. Also, PowerPoint introductions can make more grounded associations in students' cerebrums (Baker et al., 2018; Chou et al., 2015) . Partaking in different interchanges in the language being instructed is another fundamental condition for effective language learning. A large portion of the students don't have such chances. Nonetheless, so far exceptional consideration has been paid to making these open doors in instructing with the assistance of current advancements and e-realizing so students can convey well in English. Endeavors here can be assembled into two classes: correspondence and discussion with the PC itself and correspondence and discussion with the assistance of PCs with the far-off crowd.

Students are a significant factor in changing the world. Subsequently, proceeding with training should be perhaps the main objectives of learning. Then, instructive innovation can serve students' deep-rooted learning. Studies have likewise indicated that in study halls that utilization innovation, students are additionally ready to work with educators, get their work done, and pick a participatory way to deal with tackling complex issues. Exploration notes on the effect of innovation on composing show that students who use consoles recorded as a hard copy can compose more effectively than pencils and pens; that is the reason students can figure out how to compose better by utilizing a ton of PC search practice to discover data on the console. Moreover, it makes it conceivable regarding any matter. Moreover, programming's, for example, data sets, bookkeeping pages, and idea maps assist students with getting sorted out and assess information and data they have gotten to on the web. Subsequently, students can communicate their contemplations and thoughts plainly and inventively utilizing correspondence media, for example, words, pictures, general media and different advances (Jurkovič, 2019; Liu \& Song, 2021). In like manner, when students feel they can accomplish something with their educators, guardians, and schoolmates, they feel fulfilled. In the study hall, a few educators will in general utilize advanced media to fortify essential aptitudes in students by utilizing picture and video innovation, they can bring the world external the homeroom into the homeroom. The above layouts the fate of learning for students. Hence, it is important to give the ground to the utilization of new innovation in the getting the hang of showing measure at the earliest opportunity. In any case, students can utilize these advances. 


\section{Conclusion}

The use of PC resources such as e-learning can help teachers in the classroom and remember that it enhances training ideas and makes students excited to learn. Ongoing advances in the PC and data industry and the arrival of environmental, provincial, and global data organizations, particularly the Internet, have brought new media, correspondence innovations, instruments, and strategies to designers, organizers, directors, and instructive project heads. Ordinary learning designs have advanced and clients are presented with large sizes of information and data. English combines several specific skills (tuning, speaking, writing, and so on), and local school students face many challenges in actually learning these number of skills by using new ways and strategies along with proper preparation materials that can deal with many student problems. Meanwhile, the use of PC assets such as e-learning can help educators in the homeroom and remember that improving the nature of teaching, makes students eager to learn.

\section{References}

Anderson, D. R., \& Davidson, M. C. (2019). Receptive versus interactive video screens: A role for the brain's default mode network in learning from media. Computers in Human Behavior, 99, 168-180. https://doi.org/10.1016/j.chb.2019.05.008.

Arrosagaray, M., González-Peiteado, M., Pino-Juste, M., \& Rodríguez-López, B. (2019). A comparative study of Spanish adult students' attitudes to ICT in classroom, blended and distance language learning modes. Computers and Education, 134, 31-40. https://doi.org/10.1016/j.compedu.2019.01.016.

Baker, J. P., Goodboy, A. K., Bowman, N. D., \& Wright, A. A. (2018). Does teaching with PowerPoint increase students' learning? A meta-analysis. Computers and Education, 126, 376-387. https://doi.org/10.1016/j.compedu.2018.08.003.

Chen, H. T. M., \& Thomas, M. (2020). Effects of lecture video styles on engagement and learning. Educational Technology Research and Development, 68(5), 2147-2164. https://doi.org/10.1007/s11423-020-09757-6.

Chou, P. N., Chang, C. C., \& Lu, P. F. (2015). Prezi versus PowerPoint: The effects of varied digital presentation tools on students' learning performance. Computers and Education, 91, 73-82. https://doi.org/10.1016/j.compedu.2015.10.020.

Glaveanu, V. P., Ness, I. J., \& de Saint Laurent, C. (2020). Creativity, Learning and Technology: Opportunities, Challenges and New Horizons. Creativity Research Journal, 32(1), 1-3. https://doi.org/10.1080/10400419.2020.1712167.

Gogate, M., Dashtipour, K., Adeel, A., \& Hussain, A. (2020). CochleaNet: A robust language-independent audio-visual model for real-time speech enhancement. Information Fusion, 63, 273-285. https://doi.org/10.1016/j.inffus.2020.04.001.

Hao, M., Cao, W. H., Liu, Z. T., Wu, M., \& Xiao, P. (2020). Visual-audio emotion recognition based on multi-task and ensemble learning with multiple features. Neurocomputing, 391, 42-51. https://doi.org/10.1016/j.neucom.2020.01.048.

Huang, Y., Richter, E., Kleickmann, T., Wiepke, A., \& Richter, D. (2021). Classroom complexity affects student teachers' behavior in a VR classroom. Computers and Education, 163, 104100. https://doi.org/10.1016/j.compedu.2020.104100.

Jurkovič, V. (2019). Online informal learning of English through smartphones in Slovenia. System, 80, 27-37. https://doi.org/10.1016/j.system.2018.10.007.

Lazonder, A. W., Walraven, A., Gijlers, H., \& Janssen, N. (2020). Longitudinal assessment of digital literacy in children: Findings from a large Dutch single-school study. Computers and Education, 143(September 2019), 103681. https://doi.org/10.1016/j.compedu.2019.103681. 
Liu, H., \& Song, X. (2021). Exploring "Flow" in young Chinese EFL learners' online $\begin{array}{llll}\text { English learning } & \text { activities. System, 96, }\end{array}$ https://doi.org/10.1016/j.system.2020.102425.

Mayer, R. E., Fiorella, L., \& Stull, A. (2020). Five ways to increase the effectiveness of instructional video. Educational Technology Research and Development, 68(3), 837852. https://doi.org/10.1007/s11423-020-09749-6.

Ogawa, N., Kanematsu, H., Barry, D. M., Shirai, T., Kawaguchi, M., Yajima, K., Nakahira, K. T., Suzuki, S. N., Kobayashi, T., \& Yoshitake, M. (2020). Active learning classes (in kosen colleges of Japan) using ICT and tools for obtaining biological information to enhance the creativity of engineering design students. Procedia Computer Science, 176, 2108-2116. https://doi.org/10.1016/j.procs.2020.09.247.

Scagnoli, N. I., Choo, J., \& Tian, J. (2019). Students' insights on the use of video lectures in online classes. British Journal of Educational Technology, 50(1), 399-414. https://doi.org/10.1111/bjet.12572.

Seçer, Ş. Y. E., Şahin, M., \& Alc1, B. (2015). Investigating the Effect of Audio Visual Materials as Warm-up Activity in Aviation English Courses on Students' Motivation and Participation at High School Level. Procedia - Social and Behavioral Sciences, 199, 120-128. https://doi.org/10.1016/j.sbspro.2015.07.495.

Valtonen, T., Kukkonen, J., Kontkanen, S., Sormunen, K., Dillon, P., \& Sointu, E. (2015). The impact of authentic learning experiences with ICT on pre-service teachers' intentions to use ICT for teaching and learning. Computers and Education, 81, 49-58. https://doi.org/10.1016/j.compedu.2014.09.008. 